\title{
COVID 19 infection and mucormycosis-a dangerously increasing combination
}

Satvinder Singh Bakshi ${ }^{*}$ (D) and Vinoth Kumar Kalidoss ${ }^{2}$

Keywords: COVID 19, Mucormycosis, Glucocorticoids

To the editor,

\section{Background}

With the current pandemic of coronavirus disease 2019 (COVID-19) raging, there has been a frantic search for treatment options. Out of the several treatment options that have been tried with varying degrees of success, systemic glucocorticoids have been shown to improve survival in COVID-19. Unfortunately, the widespread use of glucocorticoids has also led to an increase in the side effects of these drugs especially an increase in secondary bacterial or fungal infections. COVID-19-associated pulmonary aspergillosis (CAPA) complicating the course of COVID-19 has widely been reported; there are only a few reports on mucormycosis $[1,2]$, probably due to the lack of clinical suspicion and difficulty in isolation of causative fungi.

\section{Main text}

Mucormycosis is an acute or subacute rapidly progressing infections caused by the angioinvasive fungi in the order of Mucorales [3]. It most commonly affects patients with poorly controlled diabetes mellitus and immunocompromised patients, leading to significant morbidity and mortality. The most common region affected is the nose, paranasal sinus, and brain leading to rhino-orbital and rhino-cerebral mucormycosis; this is also seen in the present pandemic and most of the case reports are of rhino-orbito-cerebral mucormycosis [4]; however, there are reports of pulmonary [1] and gastrointestinal mucormycosis too [5]. The cause

\footnotetext{
* Correspondence: saty.bakshi@gmail.com

'Department of ENT and Head \& Neck Surgery, AllMS Mangalagiri, Guntur,

Andhra Pradesh 522503, India

Full list of author information is available at the end of the article
}

for increased mucor infection in patients is complex and includes an interplay of factors, like pre-existing diseases, such as diabetes mellitus; use of immunosuppressive therapy like glucocorticoids and tocilizumab; pre-existing lung conditions; and systemic immune alterations by the virus itself like reduced number of $\mathrm{T}$ lymphocytes, $\mathrm{CD} 4+\mathrm{T}$, and CD8+T cells [4].

Many challenges have also emerged in the management of mucormycosis during this pandemic. Early detection, control of hyperglycemia, liposomal amphotericin B, and surgical debridement are the cornerstones in the successful management of mucormycosis. However, in the current scenario, it is difficult to control the hyperglycemia due to the extensive use of steroids, most operation theaters remain shut due to diversion of manpower and other resources to other departments; therefore, delaying surgical debridement and the presence of coexisting multi-organ dysfunction in these patients makes it difficult to shift them for imaging studies.

\section{Conclusion}

In this scenario, it is imperative that clinicians should be sensitized to the increased risk of development of this fatal infection, especially while treating diabetic coronavirusaffected patients with systemic steroids. In addition, judicious use of glucocorticoids must be advocated in all patients.

\section{Abbreviations \\ COVID-19: Corona virus 2019; CAPA: COVID-19-associated pulmonary aspergillosis}

\author{
Acknowledgements \\ None
}

Springer Open

(c) The Author(s). 2021 Open Access This article is licensed under a Creative Commons Attribution 4.0 International License which permits use, sharing, adaptation, distribution and reproduction in any medium or format, as long as you give appropriate credit to the original author(s) and the source, provide a link to the Creative Commons licence, and indicate if changes were made. The images or other third party material in this article are included in the article's Creative Commons licence, unless indicated otherwise in a credit line to the material. If material is not included in the article's Creative Commons licence and your intended use is not permitted by statutory regulation or exceeds the permitted use, you will need to obtain permission directly from the copyright holder. To view a copy of this licence, visit http://creativecommons.org/licenses/by/4.0/. 


\section{Authors' contributions}

SSB and VKK contributed to the manuscript concept, design, acquisition of the data, and writing and revising of the original draft. All authors have read and approved the final manuscript.

\section{Funding}

No funding was obtained.

Availability of data and materials

Not applicable

\section{Declarations}

Ethics approval and consent to participate

Not applicable

\section{Consent for publication}

Not applicable

\section{Competing interests}

The authors declare that they have no competing interests.

\section{Author details}

'Department of ENT and Head \& Neck Surgery, AllMS Mangalagiri, Guntur, Andhra Pradesh 522503, India. ${ }^{2}$ Department of Community and Family

Medicine, AllMS Mangalagiri, Guntur, Andhra Pradesh 522503, India.

Received: 2 May 2021 Accepted: 19 May 2021

Published online: 27 May 2021

\section{References}

1. Garg D, Muthu V, Sehgal IS, Ramachandran R, Kaur H, Bhalla A et al (2021)

Coronavirus disease (Covid-19) associated mucormycosis (CAM): case report and systematic review of literature. Mycopathologia. 5:1-10. https://doi. org/10.1007/s11046-021-00528-2

2. Veisi A, Bagheri A, Eshaghi M, Rikhtehgar MH, Rezaei Kanavi M, Farjad R (2021) Rhino-orbital mucormycosis during steroid therapy in COVID-19 patients: a case report. Eur J Ophthalmol 10:11206721211009450

3. Bakshi SS (2019) Rhino-orbital mucormycosis. Bull Emerg Trauma 7(1):88-89. https://doi.org/10.29252/beat-0701015

4. John TM, Jacob CN, Kontoyiannis DP (2021) When uncontrolled diabetes mellitus and severe COVID-19 converge: the perfect storm for mucormycosis. J Fungi Basel Switz 7(4):298

5. do Monte Junior ES, Santos MELD, Ribeiro IB, Luz G d O, Baba ER, Hirsch BS et al (2020) Rare and fatal gastrointestinal mucormycosis (zygomycosis) in a COVID-19 patient: a case report. Clin Endosc 53(6):746-749

\section{Publisher's Note}

Springer Nature remains neutral with regard to jurisdictional claims in published maps and institutional affiliations.

\section{Submit your manuscript to a SpringerOpen ${ }^{\circ}$ journal and benefit from:}

- Convenient online submission

- Rigorous peer review

- Open access: articles freely available online

- High visibility within the field

- Retaining the copyright to your article 